Bull. Geol. Soc. Finland 41, 79-84 (1969)

\title{
KORNERUPINE-BEARING GNEISS FROM INANAKAFY NEAR BETROKA, MADAGASCAR
}

\author{
Oleg v. Knorring *, Th. G. Sahama ** and Martiti Lehtinen ** \\ * Dept. of Geology, Leeds University, U. K. \\ ** Dept. of Geology, University of Helsinki, Finland
}

\begin{abstract}
This paper presents mineralogical data for the constituents of a kornerupine-bearing gneiss from Inanakafy near Betroka, Madagascar. Chemical analyses are given of the phlogopite, kornerupine, orthopyroxene and cordierite occurring in the rock. The unit cell content of kornerupine is discussed.
\end{abstract}

On a visit to Madagascar in 1967 the first two authors were privileged to obtain a couple of specimens of a highly metamorphic gneiss containing abundant kornerupine. The rock was said to come from Inanakafy near Betroka. The field association of the rock is not known to the authors. Because more recent data for the Madagascar kornerupine and for its mineral paragenesis are not available in literature, the Inanakafy rock was subjected to a mineralogical study. The results will be presented in this paper.

The rock contains the following constituents listed in order of estimated abundance: phlogopite, kornerupine, orthopyroxene and cordierite, with tourmaline, plagioclase, spinel, sapphirine and zircon as accessories. Pure fractions or the four main constituents were prepared by hand picking, heavy liquids and magnetic separator. The results of the chemical analyses made on these constituents are summarized in Table 1.

\section{Phlogopite}

Black phlogopite represents the most abundant constituent of the rock. The flakes are mostly anhedral. Sometimes, however, prismatic faces and, very rarely, poorly developed pyramidal ones are to be seen. The flakes range up to $1 \mathrm{~cm}$ in diameter. The chemical composition is given in Table 1. Based on $(\mathrm{O}, \mathrm{OH}, \mathrm{F})=$ 24, the unit cell content is as follows: Si 5.67, Al 2.80, $\mathrm{Fe}^{3+0.18}, \mathrm{Fe}^{2+} 0.32, \mathrm{Mg}$ 5.02, Ti 0.11, $\mathrm{Ca} 0.18, \mathrm{Na} 0.15, \mathrm{~K} 1.20, \mathrm{~F} 0.42$, OH 3.14 . The powder pattern is characteristic of a trioctahedral mica. Precession photographs were taken about the $a$ - and $b$-axes. The $b k l$ reflections with $k \neq 3 n$ appear as streaks parallel to $c^{*}$. These streaks contain intensity maxima consistent with the $3 T$ polytype. Accordingly, the mica represents a somewhat disordered stacking sequence with dominating $3 T$ or twinned $1 M$. 
TABLE 1

Chemical composition of kornerupine, orthopyroxene, cordierite and phlogopite from Inanakafy near Betroka, Madagascar

\begin{tabular}{|c|c|c|c|c|}
\hline & Kornerupine $\left.{ }^{1}\right)$ & Orthopyroxene $\left.{ }^{1}\right)$ & 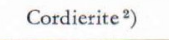 & Phlogopite $\left.{ }^{2}\right)$ \\
\hline $\mathrm{SiO}_{2} \ldots \ldots \ldots \ldots$ & $30.90 \%$ & $53.39 \%$ & $49.63 \%$ & $40.72 \%$ \\
\hline $\mathrm{B}_{2} \mathrm{O}_{3} \ldots \ldots \cdots \cdots \cdots \cdots \cdots \cdots \cdots \cdots \cdots \cdots \cdots$ & 3.45 & - & - & -- \\
\hline 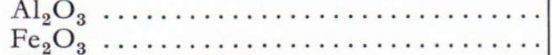 & 41.45 & 5.44 & $\begin{array}{r}34.40 \\
0.23\end{array}$ & 17.05 \\
\hline 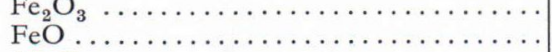 & $\begin{array}{l}1.72 \\
2.65\end{array}$ & 1.51 & 0.23 & 1.68 \\
\hline $\mathrm{MnO} \ldots \ldots$ & $\begin{array}{l}2.65 \\
0.06\end{array}$ & $\begin{array}{l}8.41 \\
0.12\end{array}$ & $\begin{array}{l}1.53 \\
\text { trace }\end{array}$ & $\begin{array}{l}2.73 \\
0.02\end{array}$ \\
\hline ............. & 18.62 & 30.86 & 12.77 & 24.18 \\
\hline $\mathrm{TiO}_{2} \ldots \ldots$ & 0.07 & 0.10 & trace & 1.04 \\
\hline $\mathrm{CaO}^{2}$ & none & none & 0.61 & 1.19 \\
\hline $\mathrm{Na}_{2} \mathrm{O} \quad \ldots \ldots \ldots \ldots \ldots \ldots \ldots \ldots \ldots \ldots \ldots \ldots$ & 0.12 & 0.06 & 0.30 & 0.55 \\
\hline$\underset{\mathrm{F}}{\mathrm{K}_{2} \mathrm{O}} \ldots \ldots \ldots \ldots \ldots \ldots \ldots \ldots \ldots \ldots \ldots \ldots \ldots \ldots \ldots \ldots \ldots$ & trace & trace & none & 6.74 \\
\hline$F$ & - & - & - & 0.96 \\
\hline $\begin{array}{l}\mathrm{H}_{2} \mathrm{O}+{ }^{2} \\
\mathrm{H}_{2} \mathrm{O}-{ }^{2}{ }^{2}\end{array}$ & 1.08 & 0.30 & 0.34 & 3.38 \\
\hline $\mathrm{H}_{2} \mathrm{O}-\ldots \ldots \ldots \ldots \ldots \ldots \ldots \ldots \ldots \ldots \ldots \ldots \ldots \ldots$ & 0.00 & $\begin{array}{l}0.04 \\
\end{array}$ & $\underline{0.00}$ & $\begin{array}{r}0.06 \\
100.30\end{array}$ \\
\hline$-\mathrm{O} \ldots \ldots \ldots$ & - & - & - & 0.40 \\
\hline Total & 100.12 & 100.23 & 99.81 & 99.90 \\
\hline$\left.d^{3}\right)$ & $3.31 \pm 0.01$ & $3.31 \pm 0.03$ & $2.57 \pm 0.02$ & $2.91 \pm 0.01$ \\
\hline
\end{tabular}

1) Analysis by Oleg v. Knorring.

2) Analysis by Tapio Koljonen.

3) Berman balance.

The refractive indices (sodium light) are: $\alpha=$ $1.558, \beta=1.601, \gamma=1.602$, all \pm 0.001 . Optically negative. $2 \mathrm{~V}$ varies from almost zero to ca. $9^{\circ}$.

\section{Kornerupine}

Kornerupine occurs in the rock as abundant prismatic crystals up to $3-4 \mathrm{~cm}$ long and $1 \mathrm{~cm}$ thick. The prisms show the faces $\{100\},\{010\}$ and $\{110\}$. End faces are extremely rare and poorly developed. Only $\{111\}$ could be identified. No good cleavage.

The mineral is optically negative with a negative sign of elongation. $\gamma \sim \beta=1.684, \alpha=$ 1.672 , both \pm 0.001 (sodium light). Birefringence with Berek compensator on accurately oriented plates: $\gamma-\beta=0.0001_{5}$ and $\beta-\alpha=$ 0.0139 . These values correspond to $2 V_{\alpha}{ }_{\alpha}=12^{\circ}$. The large core of the crystal displays an undulating extinction and is surrounded by a narrow 'zoned' margin. The interference colors are anomalous. The anomalies in the optical properties which are caused by crystallization under varying strain conditions are visible on (001) only and must be taken into account when determining the optic axial angle. The optic axial angle was measured from the interference figure. The value $2 \mathrm{~V}=12^{\circ}$ was considered most probable for the unstrained crystal. Dispersion of $2 V$ inclined with $r>v$. The optic axial plane is (100). Upon heating the optic axial angle decreases, reaches zero at ca. $80^{\circ}-100^{\circ} \mathrm{C}$ and opens up rapidly in a direction perpendicular to the original optic axial plane (microscope heating stage). Pleochroism is strong on thick plates: $\gamma \sim \alpha$ pale yellowish brown, $\beta$ deep bluish green. Absorption: $\beta \gg \gamma \backsim \alpha$. In thin section, colorless without pleochroism. The indicatrix is oriented a $\|\beta, \mathrm{b}\| \gamma, \mathrm{c} \| \alpha$.

Bartl (1965) and McKie (1965) reported for kornerupine the diffraction symbol $m m m C . c$. 
which corresponds to the space groups $C \mathrm{mcm}$, $C m c 2_{1}$ and $C 2 \mathrm{~cm}$. A series of precession photographs about all three crystallographic axes confirmed this diffraction symbol for the Inanakafy mineral. The $\mathrm{X}$-ray powder pattern (Phillips Norelco) agrees closely with that tabulated by McKie for the Mautia Hill kornerupine, except that the $d$-values are slightly lower for the Inanakafy mineral. Adopting the setting proposed by McKie, the unit cell dimensions were calculated from the lines 002, 022, 530, 023, 640 and 550 with the result: $a_{0}=15.97 \pm$ $0.01 \AA, b_{0}=13.74 \pm 0.01 \AA$ and $c_{0}=6.70 \pm$ $0.005 \AA$.

The chemical composition is given in Table 1 . The unit cell content will be discussed at the end of this paper.

\section{Orthopyroxene}

The euhedral to subhedral orthopyroxene is brownish in a hand specimen. Fig. 1 illustrates the crystal habit characterized by the pyramidal faces $\{211\}$. Faces $\{101\}$ not visible. The mineral is rich in aluminum (Table 1). Neglecting $\mathrm{Na}_{2} \mathrm{O}$ and $\mathrm{H}_{2} \mathrm{O}$, the unit cell content, based on $\mathrm{O}=48$, is as follows: $\mathrm{Si} 14.95, \mathrm{Al} 1.80, \mathrm{Fe}^{3+} 0.32, \mathrm{Fe}^{2+}$ 1.97, Mn 0.03, Mg 12.88, Ti 0.02. The mineral represents a bronzite with (Fe, $\mathrm{Mn}): \mathrm{Mg}=$ 15:85 and with Al largely substituting for Si.

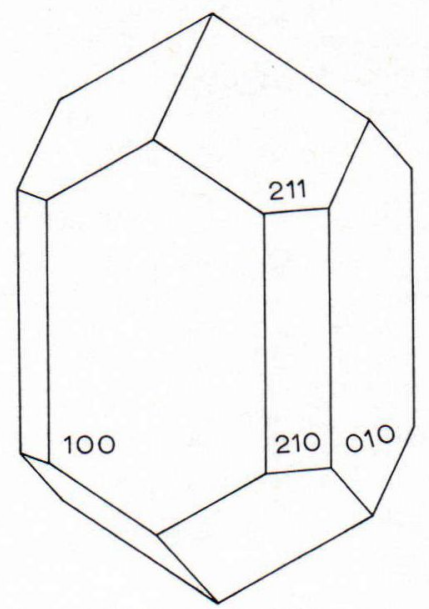

Fig. 1. Crystal habit of the orthopyroxene from Inanakafy, Madagascar.
The X-ray powder pattern (Philips Norelco) was indexed according to the data by Swanson et al. (1956) except that the indices $b$ and $k$ were interchanged to correspond to the conventional setting. The unit cell dimensions were calculated from the powder pattern: $a_{0}=18.27 \pm 0.01 \AA$, $b_{o}=8.806 \pm 0.005 \AA, c_{o}=5.187 \pm 0.005 \AA$. These cell parameters are well in accordance with those compiled by Howie (1963) for Alrich bronzite. A series of precession photographs about all three crystallographic axes revealed the space group Pbca. The mineral is colorless without pleochroism in thin section. In thick sections it is weakly pleochroic with $\gamma$ slightly greenish and $\alpha \sim \beta$ brownish. Refractive indices in sodium light: $\alpha=1.675, \beta=1.680, \gamma=1.686$, all \pm $0.001 .2 \mathrm{~V}$ nearly $90^{\circ}$.

\section{Cordierite}

Cordierite is relatively abundant in the rock and occurs largely as oval-shaped monomineralic aggregates with a slightly bluish color. No crystal faces were visible. The chemical composition reproduced in Table 1 shows the mineral to represent a very $\mathrm{Mg}$-rich variety with ca. $7 \mathrm{~mol} . \%$ of the iron component. The unit cell content, based on $\mathrm{O}=72$, is as follows: Si 19.68, Al 16.08, $\mathrm{Fe}^{3+} 0.07, \mathrm{Fe}^{2+} 0.51, \mathrm{Mg} 7.55$, Ca 0.26, $\mathrm{Na} 0.23, \mathrm{H}_{2} \mathrm{O} 0.45$. Unit cell dimensions calculated from the X-ray powder pattern on the basis of the lines $310,002,112,402,222,131$, 622, 442, 533, 642: $a_{0}=17.06 \pm 0.01 \AA, b_{0}=$ $9.722 \pm 0.005 \AA, c_{o}=9.359 \pm 0.005 \AA$. Distortion index 0.26 . Systematic extinctions found in a series of precession photographs about the $a$ - and $b$-axes agree with the requirements of the space group $C \mathrm{ccm}$. Refractive indices in sodium light: $\alpha=1.532, \beta=1.537, \gamma=1.542$, all \pm $0.001 .2 V=81^{\circ} \pm 2^{\circ}$ (universal stage). Optically positive. Often multiply twinned on (110).

\section{Accessories}

The most abundant accessory constituent is tourmaline. It is black in a hand specimen and 
strongly pleochroic from greenish to colorless in thin section. The identification was confirmed by powder pattern.

Twinned plagioclase occurs in sparing amounts. Refractive indices on cleavage fragments are $\gamma^{\prime}=1.560, \alpha^{\prime}=1.551$, both \pm 0.001 . These values correspond to ca. $44 \mathrm{~mol}$. \% An.

Small amounts of a blue spinel were extracted with heavy liquids and identified by powder pattern. Octahedral faces were sometimes visible. $a_{o}=8.105 \pm 0.001 \AA$ corresponding to that of a pure $\mathrm{MgAl}$-spinel.

In the heavy liquid fraction of spinel, a small number of slightly greenish blue crystals was obtained. The powder pattern indicated that the mineral was sapphirine. A few grains of this mineral were also detected in thin section.

Some few euhedral crystals of zircon were found in thin section and in the crushed rock material.

\section{Unit cell content of kornerupine}

Since the discovery of boron as an essential cation in the kornerupine structure (Lacroix and de Gramont, 1921), the unit cell content of the mineral has been discussed by several authors. The main problem was confined to the number of oxygen $(+\mathrm{OH})$ atoms to be attributed to the unit cell. Hey et al. (1941) pointed out that the chemical analyses of kornerupine available at that time were compatible with 86 oxygen atoms per cell and their formula was adopted by Girault (1952). De Villiers (1940) suggested 90 oxygen atoms per cell for the Port Shepstone kornerupine.

The establishment of the true space group (Cmcm, Cmc2,$C 2 \mathrm{~cm}$ ) by Bartl (1965) and McKie (1965) made it evident that the number of oxygen atoms in the kornerupine unit cell must be a multiple of four. Bartl (op. cit.) made an X-ray study of the Waldheim kornerupine

1) The numbers of the kornerupine specimens mentioned later in the text refer to the numbering in this list. ('prismatine') and found that 56 cations and 84 anions were most compatible with the analysis and density reported by Hey et al. (op. cit.). Simultaneously with Bartl, McKie (op.cit.) suggested $\mathrm{O}+\mathrm{OH}=88$ for the Mautia Hill mineral.

The brief review just presented reflects the uncertainty connected with the general chemical formula to be assigned to kornerupine. Essentially new information was produced by Moore and Bennett (1968). These authors presented a crystal structure determination of the Mautia Hill kornerupine. Adopting $\mathrm{O}+\mathrm{OH}=88$ and the space group $\mathrm{Cmcm}$ they arrived at the simplified formula

$$
\mathrm{Mg}_{12} \mathrm{Al}_{24}(\mathrm{Si}, \mathrm{Al})_{20} \mathrm{O}_{84}(\mathrm{OH})_{4} \text {. }
$$

This formula, which results from a very complicated type of crystal structure, requires 56 cations in the unit cell.

In discussing the unit cell content of kornerupine the following chemical analyses of the mineral will be considered ${ }^{1}$ ):

No. 1. Port Shepstone, Natal, South Africa. de Villiers (1940); Hey et al. (1941).

2. Lac Ste-Marie, Quebec, Canada. Yellow variety. Girault (1952).

3. Lac Ste-Marie, Quebec, Canada. Green variety. Girault (1952).

4. Ellamkovilpatti, Madras, India. Balasubrahmanyan (1965).

5. Waldheim, Saxony. Hey et al. (1941).

6. Inanakafy, Madagascar. This paper.

7. Mautia Hill, Tanzania. McKie (1965).

8. Ceylon, Normal type. Hey et al. (1941), anal. I.

9. Ceylon. Optically pseudo-uniaxial type. Hey et al. (1941), anal. III.

10. Itrongay, Madagascar. Lacroix (1922); Hey et al. (1941).

Inspection of the original analyses, not reproduced here, reveals the fact that the contents of $\mathrm{Ca}$ and the alkalies are negligible in Nos. 2, 3, 4, 6, 7 and 8. (Since Nos. 2 and 3 show some $\mathrm{P}_{2} \mathrm{O}_{5}$, the small amounts of $\mathrm{CaO}$ in these specimens are probably mainly contained in apatite 
TABLE 2

Chemical composition of selected kornerupine specimens. Neglecting $\mathrm{CaO}, \mathrm{Na}_{2} \mathrm{O}, \mathrm{K}_{2} \mathrm{O}, \mathrm{P}_{2} \mathrm{O}_{5}, \mathrm{H}_{2} \mathrm{O}$ A. Reduced to $100 \%$

\begin{tabular}{|c|c|c|c|c|c|}
\hline & \multicolumn{5}{|c|}{ Kornerupine No. } \\
\hline & 2 & 3 & 4 & 6 & 7 \\
\hline 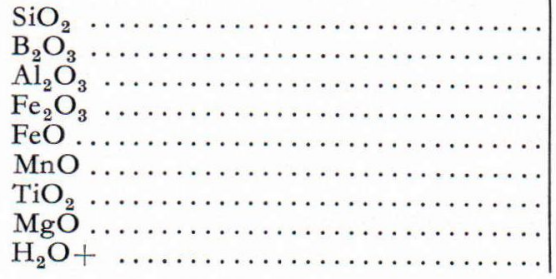 & $\begin{array}{l}30.49 \% \\
3.31 \\
42.41 \\
0.91 \\
9.19 \\
\text { trace } \\
12.62 \\
1.07\end{array}$ & $\begin{array}{c}30.44 \% \\
3.52 \\
41.13 \\
0.42 \\
8.55 \\
\text { trace } \\
\\
14.97 \\
0.97\end{array}$ & $\begin{array}{l}31.00 \% \\
2.39 \\
43.90 \\
\left.4.66^{1}\right) \\
0.09 \\
0.15 \\
17.46 \\
0.35\end{array}$ & $\begin{array}{r}30.90 \% \\
3.45 \\
41.45 \\
1.72 \\
2.65 \\
0.06 \\
0.07 \\
18.62 \\
1.08\end{array}$ & $\begin{array}{r}29.99 \% \\
1.93 \\
43.57 \\
3.99 \\
\text { nil } \\
0.05 \\
0.16 \\
20.01 \\
0.30\end{array}$ \\
\hline
\end{tabular}

1) Total iron.

B. Unit cell content based on $\mathrm{O}+\mathrm{OH}=88$

\begin{tabular}{|c|c|c|c|c|c|}
\hline $\mathrm{Si} \ldots \ldots \ldots \ldots \ldots \ldots \ldots \ldots \ldots$ & 15.28 & 15.23 & 15.39 & 15.13 & 14.86 \\
\hline 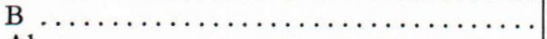 & 2.86 & 3.04 & 2.05 & 2.92 & 1.65 \\
\hline 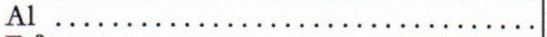 & 25.05 & 24.25 & 25.70 & 23.93 & 25.44 \\
\hline 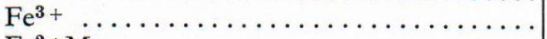 & 0.34 & 0.16 & - & 0.63 & 1.49 \\
\hline 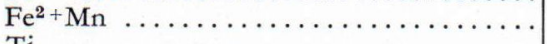 & 3.85 & 3.58 & 1.98 & 1.11 & 0.02 \\
\hline Ti $\ldots \ldots \ldots \ldots \ldots \ldots \ldots \ldots \ldots \ldots \ldots \ldots \ldots$ & - & - & 0.06 & 0.03 & 0.06 \\
\hline 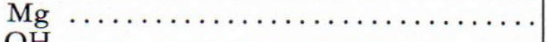 & 9.43 & 11.17 & 12.92 & 13.59 & 14.78 \\
\hline 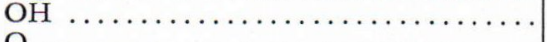 & 3.58 & 3.24 & 1.16 & 3.53 & 0.99 \\
\hline 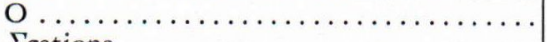 & 84.42 & 84.76 & 86.84 & 84.47 & 87.01 \\
\hline$\Sigma$ cations $\ldots \ldots \ldots \ldots \ldots \ldots \ldots \ldots \ldots \ldots$ & 56.81 & 57.43 & 58.10 & 57.34 & 58.30 \\
\hline
\end{tabular}

inclusions). The significant contents of $\mathrm{Ca}$ and the alkalies are considered as due to alteration or contamination in Nos. 1 and 5 and due to anomalous composition or possibly to the uncertainty of the wet chemical analysis in Nos. 9 and 10, (resulting from the very small amounts of material available). Neglecting $\mathrm{CaO}, \mathrm{Na}_{2} \mathrm{O}$, $\mathrm{K}_{2} \mathrm{O}, \mathrm{P}_{2} \mathrm{O}_{5}$ and $\mathrm{H}_{2} \mathrm{O}$-, the compositions of Nos. 2, 3, 4, 6 and 7 are reproduced in Table $2 \mathrm{~A}$ and the unit cell contents, based on $\mathrm{O}+\mathrm{OH}$ $=88$, in Table $2 \mathrm{~B}$.

Moenke (1962) studied the infrared absorption of a number of borosilicate minerals and concluded that the Waldheim kornerupine (No. 5) contains boron in a fourfold coordination only. The infrared absorption spectrum of the Inanakafy mineral confirms Moenke's data for the Waldheim mineral. Table 2 indicates that the actual boron content found in kornerupine is insufficient to warrant occupation of a separate fourfold site in the unit cell. Being almost constantly associated with tourmaline, natural kornerupine does not seem capable of accomodating much more boron than three atoms per cell. Because, on the other hand, no boron-free kornerupine has ever been found, a certain boron content appears to favor the crystallization of the mineral. The crystallochemical formula of kornerupine proposed by Moore and Bennett (1968) includes no boron. It is simply considered equivalent to silicon.

In the kornerupine unit cell (Table 2B) the number of cations clearly exceeds 56 or, what amounts to the same, there is a deficiency in the 
number of anions. The amount of water, assumed to be as $\mathrm{OH}$, is variable and insufficient to fill four sites in the unit cell. It is feasible to suggest that these hydroxyl sites are only partially filled. A replacement of silicon by boron in fourfold coordination will also result in an anion deficiency in the formal calculation of the analysis.

Unit cell dimensions are available for Nos. 2, 6 and 7. The data reveal a gentle increase in all three cell parameters with decreasing iron content thus permitting an estimation of the unit cell dimensions of Nos. 3 and 4. The densities measured of all the specimens from Nos. 1-10 are abailable and display a clear increase with increasing iron content. Accordingly, a comparison of the calculated with the measured densities can be made for the specimens mentioned in Table 2. The densities calculated on the basis of the unit cell contents of Table 2B come out systematically slightly higher than the actually measured values. This fact is considered as further support to the assumption that the existing kornerupine analyses show an anion deficieney.

Acknowledgment. The authors are indebted to Mr. Tapio Koljonen, of the Department of Geology, University of Helsinki, for the chemical analyses of the phlogopite and cordierite.

\section{REFERENCES}

Balasubrahmanyan, M. N. (1965) Note on kornerupine from Ellamkovilpatti. Min. Mag., vol. 35, p. 662.

Barti, HaNs (1965) Zur Kornerupinstruktur. Neues Jahrb. f. Min., Monatshefte, p. 151.

Girault, J. P. (1952) Kornerupine from Lac Ste-Marie, Quebec, Canada, Amer. Miner., vol. 37, p. 531.

Hey ,Max H., Anderson, B. W. and Payne, C. J. (1941) Some new data concerning kornerupine and its chemistry. Min. Mag., vol. 26, p. 119.

Howie, R. A. (1963) Cell parameters of orthopyroxenes. Min. Soc. Am. Special Paper No. 1. IMA Third General Meeting, p. 213.

Lacroix, A. et de Gramont, A. (1919) Sur la présence $\mathrm{du}$ bore dans quelques silico-aluminates basiques naturels. Comptes Rendus, T. 168 , p. 857.

LAcrorx, A. (1922) Minéralogie de Madagascar, Tome I, p. 396.
McKIE, D. (1965) The magnesium aluminium borosilicates: kornerupine and grandidierite. Min. Mag., vol. 34 , p. 346.

Moenke, Horst (1962) Nachweis von $\mathrm{BO}_{3}$ - und $\mathrm{BO}_{4^{-}}$ Gruppen in den häufigsten natürlich gebildeten Silikaten. Silikattechnik, Bd. 13, S. 287.

Moore, Paul B. and Bennett, J. Michael (1968) Kornerupine: its crystal structure. Science, vol. 159, p. 524.

Swanson, Howard E., Gilfrich, Nancy T. and Cook, Marlene I. (1956) Standard X-ray diffraction powder patterns. Nat. Bur. Stand. Circular No. 539, vol. 6, p. 32.

DE Villiers, J. E. (1940) Iron-rich kornerupine from Port Shepstone, Natal. Min. Mag., vol. 25, p. 550.

Manuscript received, August 26, 1968. 